\title{
Movement Disorders Associated With Hemochromatosis
}

\author{
Niraj Kumar, Philippe Rizek, Bekim Sadikovic, Paul C. Adams, Mandar Jog
}

\begin{abstract}
Background: Hereditary hemochromatosis $(\mathrm{HH})$ is a genetic disorder causing pathological iron deposition and functional impairment of various organs, predominantly the liver. We assessed patients with HH for the presence of movement disorders. Methods: We reviewed the charts of 616 patients with $\mathrm{HH}$ who attended hemochromatosis clinic at London Health Sciences Centre, London, ON, Canada, from 1988 to 2015. Results: We found three HH patients with movement disorders, without any other major systemic manifestation. One had parkinsonism, another had chorea, and the third had tremor. All three patients had evidence of iron deposition in the brain, affecting the basal ganglia in the first two, and the dentate nucleus, red nucleus, and substantia nigra in the third patient. In addition to the $\mathrm{C} 282 \mathrm{Y}$ homozygous mutation in the HFE gene, two of our patients had non-HFE gene mutations. Conclusion: HH should be considered in the differential diagnosis of movement disorders with pathological brain iron deposition. We report for the first time chorea in a patient with $\mathrm{HH}$. Non-HFE gene mutations may predispose $\mathrm{HH}$ patients to iron deposition in the brain.
\end{abstract}

RÉSUMÉ: Troubles du mouvement associés à l'hémochromatose. Contexte : L'hémochromatose héréditaire (HH) est une maladie génétique qui entraîne des dépôts pathologiques de fer et des altérations fonctionnelles au niveau de différents organes, particulièrement au niveau du foie. Nous avons examiné la présence de troubles du mouvement chez des patients atteints de HH. Méthodologie : Nous avons revu les dossiers de 616 patients atteints de HH traités à la clinique d'hémochromatose du London Health Sciences Centre de London, Ontario, Canada, de 1988 à 2015. Résultats : Nous avons identifié 3 patients atteints de HH qui présentaient des troubles du mouvement sans autre manifestation systémique importante. Un patient présentait du parkinsonisme, un autre de la chorée et le troisième du tremblement. Ces trois patients avaient des dépôts de fer dans le cerveau, soit au niveau des noyaux gris centraux chez les deux premiers et dans le noyau dentelé, le noyau rouge et le locus niger chez le troisième patient. En plus de la mutation homozygote C282Y dans le gène HFE, deux de nos patients avaient des mutations génétiques qui n'étaient pas dans le gène HFE. Conclusion : L'HH devrait être incluse dans le diagnostic différentiel des troubles du mouvement chez les patients qui présentent des dépôts pathologiques de fer dans le cerveau. Nous rapportons pour la première fois de la chorée chez un patient atteint d'HH. Des mutations dans des gènes autres que HFE pourraient prédisposer les patients atteints d'HH à la formation de dépôts de fer dans le cerveau.

Keywords: Hemochromatosis, HFE Gene, Chorea, Parkinsonism, Tremor

doi:10.1017/cjn.2016.286

Can J Neurol Sci. 2016; 43: 801-808

Hereditary hemochromatosis $(\mathrm{HH})$ is a genetic disorder of iron metabolism in which progressive iron accumulation leads to pathological iron deposition and functional impairment of various organs that may become irreversible if not treated early. ${ }^{1}$ The typical hemochromatosis patient is homozygous for the $\mathrm{C} 282 \mathrm{Y}$ mutation in the HFE gene on the short arm of chromosome 6. ${ }^{1,2}$ In $\mathrm{HH}$, iron deposition predominantly occurs in the liver, pancreas, heart, joints, gonads, and skin. ${ }^{1} \mathrm{HH}$ usually does not involve the nervous system, with even fewer reported cases presenting with movement disorders. ${ }^{3-13}$ We describe three $\mathrm{HH}$ patients affected by isolated movement disorders without any other major systemic features of $\mathrm{HH}$ and review the literature with an aim to explore a possible causal relationship between $\mathrm{HH}$ and neurological manifestations.

\section{Materials AND Methods}

The hemochromatosis clinic at London Health Sciences Centre, London, ON, Canada, was started in 1988, and a multidimensional database has been created since that time on all C282Y homozygotes. All patients were assessed by the same physician (PCA) who is a recognized expert in this field. Clinical data were collected from this database reviewed by PCA, and physical examination including neurological examination was performed. The patients in the group that had isolated neurological symptoms and possible signs involving the central nervous system $(n=3)$ were separated from the entire group and referred to the movement disorder clinic. The next-generation sequencing (NGS) of these patients was extracted from the data performed at the London Health Sciences Clinical Molecular Genetics Laboratory using the hyperferritinemia gene panel. Testing involved NGS and copy number

From the Department of Clinical Neurological Sciences (NK, PR, MJ), Western University, London, ON, Canada; Department of Pathology and Laboratory Medicine (BS), Western University, London, ON, Canada; Division of Gastroenterology, Department of Medicine (PCA), Western University, London, ON, Canada.

Received February 24, 2016. Final Revisions Submitted June 8, 2016. Date of ACCEPTANCE June 30, 2016.

Correspondence to: Mandar Jog, 339 Windermere Road, A10-026, Professor, Clinical Neurological Sciences, London Health Sciences Centre, Western University, London, ON, Canada, N6A 5A5. Email: mandar.jog@lhsc.on.ca. 
analysis for 15 iron-related genes (HFE2, STEAP3, SLC4OA1, SLC25A38, TF, CP, HFE, TFR2, FTH1, CDAN1, B2M, HAMP, $F T L, S E C 23 B, A L A S 2)$ using the custom Roche Nimblegen capturebased library enrichment (Madison, WI) and Illumina NGS platform (San Diego, CA). Sequencing included all coding exons for each gene with additional 20 nucleotides of intronic sequence around each exon. This assay is clinically validated to meet the sensitivity and specificity of Sanger sequencing and multiplex ligation dependent probe amplification combined, with mean exon sequence depth of $1000 \times$ and minimum sequence depth of $100 \times$ at a single nucleotide resolution, along with custom copy number assessment of the NGS sequence data. Variants were interpreted by a certified clinical molecular geneticist (BS), and classified using the American College of Medical Genetic guidelines (PMID: 25741868). Variants classified as pathogenic, likely pathogenic, or variants of unknown clinical significance were confirmed using Sanger sequencing or multiplex ligation dependent probe amplification.

\section{RESULTS}

Clinical details were available on 616 patients (362 males and 254 females) who were $\mathrm{C} 282 \mathrm{Y}$ homozygotes. All patients underwent detailed hematological and biochemical workup for $\mathrm{HH}$ along with the genetic testing. The three patients were referred to the movement disorder clinic where they were assessed by at least one of the neurologists (NK, PR, and MJ). Examination included detailed neurological assessment including movement disorder assessment $(n=3)$ as well as other investigations as deemed necessary to rule out other possible etiologies, including neuroimaging (brain magnetic resonance imaging [MRI] scan, $n=3)$, electroencephalogram $(n=1)$, copper studies for Wilson's disease $(n=3)$, Huntington disease (HD) gene test $(n=1)$, liver Fibroscan $(n=3)$, liver MRI scan $(n=1)$, and liver biopsy $(n=1)$. Case details for each patient follow.

\section{Case Reports}

\section{Patient 1}

This 61-year-old man of Irish and Portuguese ancestry was first diagnosed with $\mathrm{HH}$ at the age of 55 years. There was incidental detection of liver iron on his MRI scan when he was involved as a control subject in a research study. He had no children. There was no family history of $\mathrm{HH}$. His initial serum ferritin level was $1183 \mu \mathrm{g} / \mathrm{l}$ with increased transferrin saturation (87.5\%). Genetic testing confirmed a C282Y homozygous mutation in the $H F E$ gene, and a heterozygous variant of unknown clinical significance c.3188C $>\mathrm{T}$ (p.Thr1063Met) in the codanin gene (congenital dyserythropoietic anemia-1, CDAN1) on NGS. Phlebotomy normalized his serum ferritin. Two years after being diagnosed with $\mathrm{HH}$, he developed rest and action tremor and loss of dexterity in his left upper limb. His cognition was preserved. He had full extraocular movements with saccadic pursuits and slow vertical saccades. He had facial hypomimia, mild hypophonia, rigidity, and bradykinesia of the left upper and lower extremities, as well as a slow shuffling gait with reduced left arm swing. Laboratory workup showed normal complete blood count, thyroid function test, creatinine, glucose, ceruloplasmin, and 24-hour urinary copper. He had no evidence of liver involvement or diabetes mellitus. His liver Fibroscan was normal. He continued on regular phlebotomy every 3 months. His brain MRI scan showed symmetrical abnormal T1 hyperintensity in the lentiform nuclei and substantia nigra bilaterally (Figure 1). He was started on levodopa-carbidopa (100/25 mg) 1 tablet by mouth four times per day. On his follow-up 6 months later, there was improvement in his parkinsonism.

\section{Patient 2}

This 64-year-old man of Scottish heritage was diagnosed with $\mathrm{HH}$ at the age of 60 when he was detected to have increased serum ferritin $(3403 \mu \mathrm{g} / \mathrm{l})$ and transferrin saturation (95\%) while being investigated for vertigo. Genetic testing confirmed a $\mathrm{C} 282 \mathrm{Y}$ homozygous mutation in the HFE gene, and heterozygous pathogenic mutation c. $212 \mathrm{G}>\mathrm{A}$ (p.Gly71Asp) in the hepcidin gene (hepcidin antimicrobial peptide, HAMP) on NGS. His family history is significant, with his brother having $\mathrm{HH}$ without neurological manifestations. He was treated with phlebotomy, which normalized his serum ferritin. An otolaryngologist ruled out peripheral causes of vertigo. Echocardiography was normal, but he had a positive tilt-table test. One year after being diagnosed with $\mathrm{HH}$, he developed intermittent left-sided, low-amplitude, choreiform movements primarily involving the fingers, and, occasionally, the hand and left foot. He had hypometric saccades, but no bradykinesia, rigidity, tremor, ataxia, or weakness. Laboratory workup showed normal serum electrolytes (sodium, potassium, and calcium), blood glucose, thyroid function test, creatine kinase, liver enzymes, bilirubin, creatinine, ceruloplasmin, and 24-hour urinary copper. He had decreased serum vitamin B12 that was supplemented. Genetic testing for HD was negative. Electroencephalogram was normal. Brain MRI scan showed T2 hypointensity with low signal on susceptibility-weighted imaging (SWI) in both caudate and lentiform nuclei, consistent with iron deposition (Figure 2), and to a lesser extent in bilateral dorsolateral nuclei of the thalami and dentate nuclei of the cerebellum. Incidental small asymptomatic bilateral cerebellar and left corona radiata infarcts were also seen. There was no evidence of liver involvement or diabetes mellitus. His liver Fibroscan was normal. His chorea improved on tetrabenazine $25 \mathrm{mg}$ oral twice daily. He developed mild parkinsonism as a side effect of tetrabenazine. His brain MRI scan was repeated after phlebotomy treatment and was unchanged.

\section{Patient 3}

This 66-year-old female patient was first diagnosed with $\mathrm{HH}$ at the age of 52 years. Her initial serum ferritin level was $1391 \mu \mathrm{g} / \mathrm{l}$ and transferrin saturation was $94 \%$. She had no family history of $\mathrm{HH}$. Genetic testing confirmed a C282Y homozygous mutation in the $H F E$ gene, without non-HFE mutations on NGS. She was initially treated with phlebotomy, which was discontinued after her serum ferritin normalized. At the age of 56, she developed tremor in her head and bilateral upper extremities. There was no history of slowness, stiffness, gait, or balance abnormality. She had normal cognition and speech. On examination, she had postural and action tremor in both upper extremities with no rest tremor. There was no appendicular ataxia and her gait was normal. Her brain MRI scan showed low signal on SWI in the dentate, red nuclei and substantia nigra, consistent with iron deposition (Figure 3). Laboratory workup showed normal complete blood count, glucose, liver and thyroid function tests, creatinine, and serum ceruloplasmin. Her liver Fibroscan was slightly abnormal at 11.8 (normal <7). Liver biopsy showed a moderate parenchymal iron overload (hepatic iron 


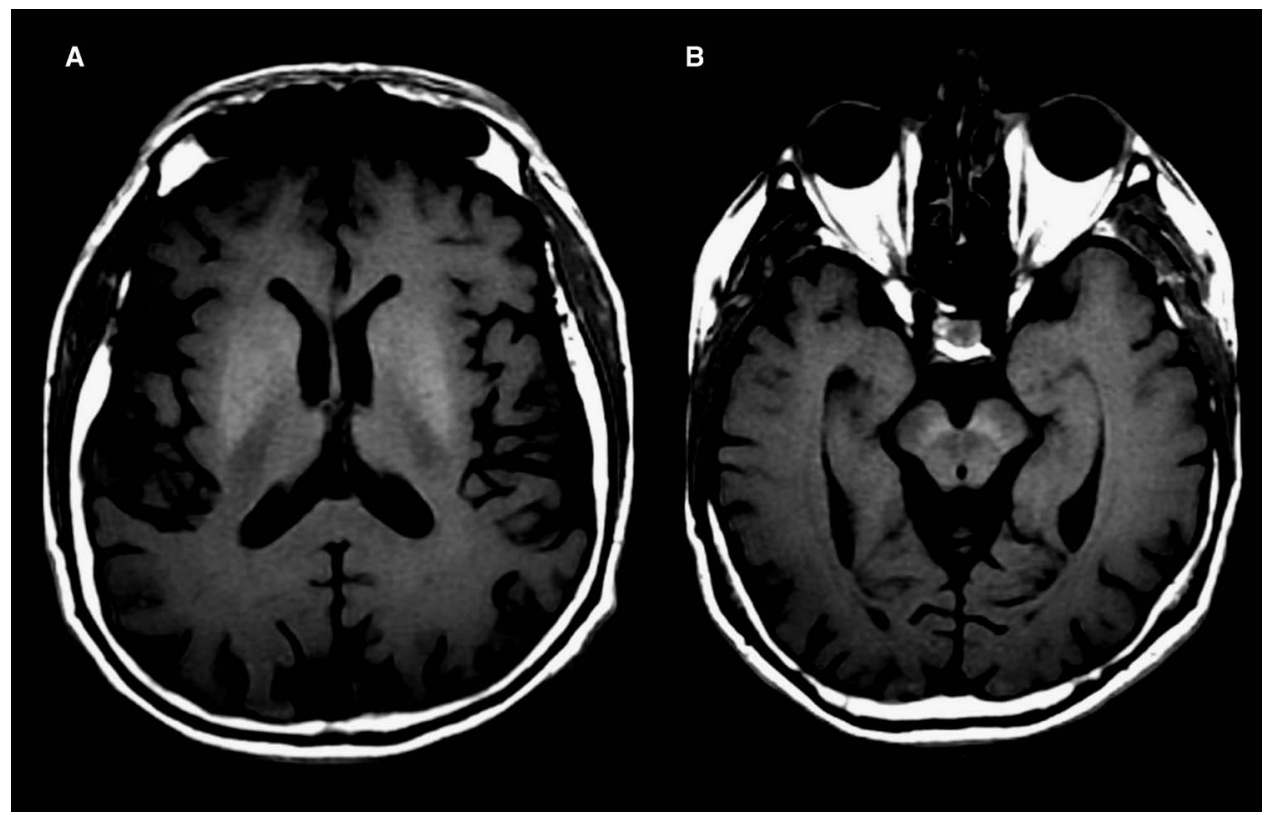

Figure 1: Brain MRI scan shows symmetrical T1 hyperintensity in the lentiform nuclei (A) and substantia nigra (B).

concentration: $145.4 \mu \mathrm{mol} / \mathrm{g}$ dry weight; reference range: 0-35) with no evidence of fibrosis, consistent with $\mathrm{HH}$. She resumed treatment at the age of 62 when her serum ferritin increased to $3513 \mu \mathrm{g} / \mathrm{l}$ and transferrin saturation reached $95.5 \%$, with a maintenance regimen of phlebotomy every 4 months after normalization of her iron stores. Her tremor improved on propranolol $40 \mathrm{mg}$ oral twice daily.

\section{Discussion}

Iron is essential for the development and functioning of the brain, and required in myelin synthesis, neurotransmitter and enzyme function, and energy production. ${ }^{14}$ The brain is second only to the liver among the organs with maximal physiological storage of iron. ${ }^{9}$ In the brain, iron distribution is not homogenous, and the globus pallidus contains the highest concentration, followed by the red nucleus, substantia nigra, putamen, and the dentate nucleus. ${ }^{14,15}$ Several neurodegenerative disorders, including Parkinson disease (PD), pantothenate kinase associated neurodegeneration, aceruloplasminemia, neuroferritinopathy, and Friedreich's ataxia, are associated with increased brain iron. ${ }^{7,14}$ Increased free iron, in disorders such as $\mathrm{HH}$, generates free radicals that lead to cellular damage by overwhelming the detoxification system of the cell. ${ }^{10}$

The blood-brain barrier is thought to protect against brain iron overload. ${ }^{14}$ The majority of $H F E$ protein resides within the brain capillaries, choroid plexus, and ependymal cells along with transferrin receptors, and influence iron uptake by the brain. ${ }^{15,16}$ This view was supported by the postmortem finding in $\mathrm{HH}$ patients with iron deposition in the choroid plexus without any abnormal basal ganglia pigmentation, ${ }^{3,17}$ however, Williams et al reported postmortem iron deposition in the basal ganglia, locus coeruleus, and dentate nuclei in a case of $\mathrm{HH}$ with parkinsonism related to multiple system atrophy, parkinsonian type. ${ }^{13}$ Iron deposition in the basal ganglia and cerebellum may cause movement disorders in $\mathrm{HH}^{11}$ The reason for the susceptibility of the basal ganglia to iron deposition is not well-understood, but it may be related to selective neuronal uptake and abnormal vascular or axonal transport along white matter tracts connecting these nuclei. ${ }^{18} \mathrm{~T} 2$ hypointensity and $\mathrm{T} 1$ hyperintensity, as well as low signal susceptibility artifact on SWI, help detect brain iron on MRI scans. ${ }^{4,5,10,11,19}$ Neuroimaging in $\mathrm{HH}$ may show basal ganglia calcification and slight sulcal prominence on brain computed tomography, ${ }^{3} \mathrm{~T} 1$ hyperintensity and $\mathrm{T} 2$ hypointensity in the basal ganglia (caudate nuclei, ${ }^{4,5}$ globus pallidus, ${ }^{4,5,10,19}$ red nuclei, ${ }^{4,5}$ substantia nigra, ${ }^{4,5}$ putamen $^{4,5,10,11,19}$ ) and dentate nuclei, ${ }^{5,11} \mathrm{~T} 2$ hyperintensity in the striatum and white matter, ${ }^{6}$ and cerebellar atrophy. ${ }^{6}$ Brain MRI of an $\mathrm{HH}$ patient with multiple system atrophy, cerebellar type, showed olivopontocerebellar atrophy and cruciform hyperintensity in the pons ("hot cross bun" sign), but failed to show pathological iron deposition. ${ }^{12}$ Few cases had normal MRI scans. ${ }^{8,9,13}$ One author describes six patients with systemic $\mathrm{HH}$ without neurological manifestations, but with neuroimaging findings suggestive of iron deposition. ${ }^{19}$ This underlines the difficulty in correlating the neurological features and brain iron deposition in $\mathrm{HH}$ patients. Two of our patients (patients 1 and 2) showed MRI changes suggestive of iron deposition in the basal ganglia; the third (patient 3) had iron deposition in the bilateral dentate, red nuclei and substantia nigra.

Genetic abnormalities in $H F E$ and related proteins may affect the blood-brain barrier in few patients with $\mathrm{HH}$, leaving their brain devoid of this protection. ${ }^{13}$ Thus, the HFE gene mutations are considered to be the prime contributor of iron overload in the brain of $\mathrm{HH}$ patients, ${ }^{15,20}$ thereby increasing the risk of neurodegenerative disorders. ${ }^{15,16,21}$ In addition to the homozygous HFE mutation (C282Y), the NGS showed an associated mutation in the $C D A N 1$ gene in patient 1 and HAMP gene in patient 2 . The mutation in the CDAN1 gene is a rare unpublished missense variant that has a relatively low population frequency (National Heart, Lung, and Blood Institute Exome Sequencing Project: EA: $\mathrm{A}=0.06 \%$; $\mathrm{AA}: \mathrm{A}=0.02 \%$ ). The mutation in the HAMP gene has 


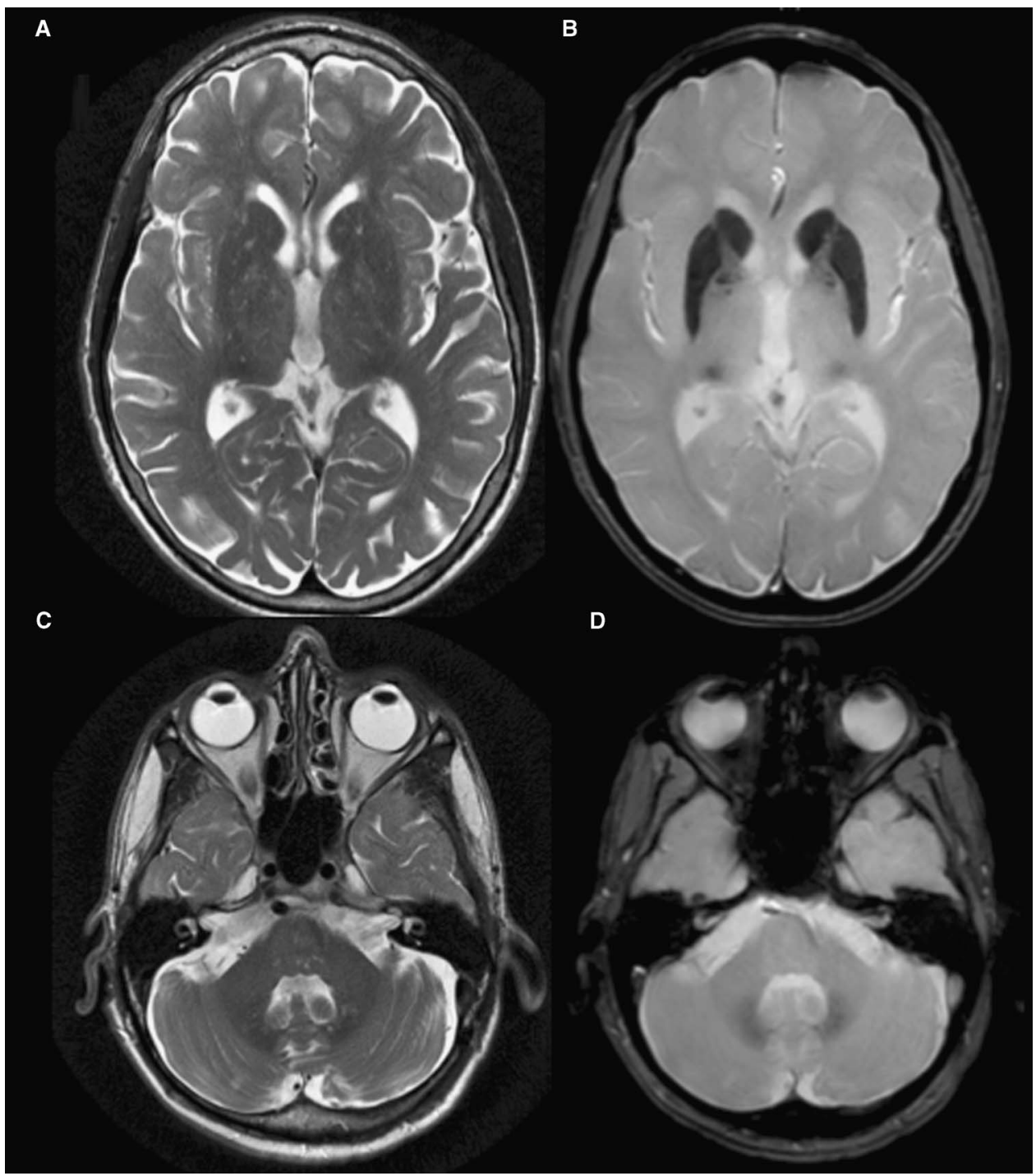

Figure 2: Brain MRI scan shows T2 hypointensity in both caudate and lentiform nuclei (A), and to a lesser extent in bilateral dentate nuclei of the cerebellum $(C)$, with corresponding low signal on SWI ( $B$ and $D$, respectively).

been previously reported in hemochromatosis, but without any movement disorder or evidence of iron deposition in the brain. ${ }^{22}$ It is possible that these non-HFE mutations may modify the phenotypic presentation of the HFE mutation. ${ }^{22}$ Thus, HFE and non-HFE mutations leading to iron accumulation in specific subcortical brain regions may explain the unusual occurrence of movement disorders in $\mathrm{HH}$.

HH usually involves the liver, pancreas, joints, skin, and gonads. ${ }^{1}$ Neurological manifestations rarely occur in HH. Neurological involvement with movement disorders in $\mathrm{HH}$ patients, including parkinsonism, ${ }^{3-6,8,9}$ Parkinson-plus syndromes, ${ }^{12,13}$ chorea, ${ }^{7}$ myoclonus, ${ }^{3,6}$ ataxia, ${ }^{3,5,6,8,11}$ dystonia, ${ }^{6,7}$ and tremor, ${ }^{4-6,10}$ with mean onset age of 57 years have been reported (Table 1). Of all the previously reported patients with $\mathrm{HH}$ and movement disorders, two had no major systemic manifestations. ${ }^{8,13}$ We report three $\mathrm{HH}$ patients, one each with parkinsonism, chorea, and tremor, without any major systemic manifestations outside the nervous system. Metabolic disturbances in systemic $\mathrm{HH}$, mainly from progressive hepatic involvement, can often produce neurological features. ${ }^{5,7}$ All three of our patients had normal liver function tests and there were no other metabolic abnormalities apart from the increased blood iron stores. Patient 1 had evidence of iron deposition in the liver on MRI scan, and patient 3 had evidence of iron deposition on liver biopsy. However, none of the three patients had cirrhosis.

The clinical-radiological correlation between the sites of brain iron deposition and neurological presentations in few reported cases suggest a causal link between $\mathrm{HH}$ and movement disorders. ${ }^{4,5,11}$ The stabilization or even reversibility of movement disorders on normalization of iron stores by phlebotomy in some of the reported cases further strengthens the causal link between $\mathrm{HH}$ and movement disorders. ${ }^{4,8,11}$ However, there are other reported cases with $\mathrm{HH}$ and movement disorders that failed to respond to phlebotomy, ${ }^{3,5,6}$ which may be explained by the prolonged insult to the brain making the pathology irreversible. ${ }^{11}$ In one report, a patient showed improvement in fatigue and headache, and the possibility of improvement in parkinsonism and 


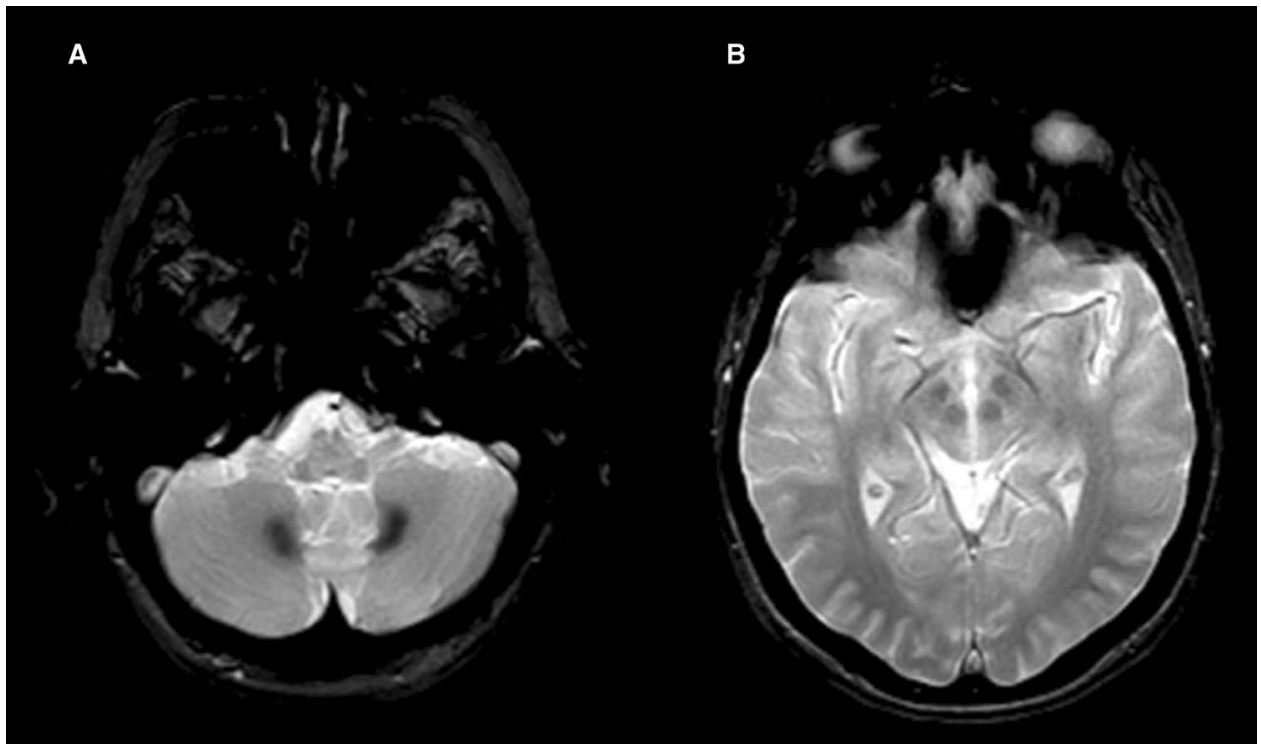

Figure 3: Brain MRI scan shows symmetrical low signal on SWI in the dentate nuclei (A), red nuclei, and substantia nigra $(B)$.

ataxia was not ruled out as the serum ferritin had not reached normal levels at the time of reporting the case. ${ }^{5}$ In another report, normalization of iron stores with phlebotomy led to reversal of brain MRI scan findings but the patient's parkinsonism and tremor improved only with deep brain stimulation of the right ventral intermediate nucleus of thalamus. ${ }^{10}$ All three of our patients improved with symptomatic drug therapy. Their failure to respond to normalization of iron stores with phlebotomy may be explained by the probably irreversible brain pathology resulting from the prolonged insult during the years of exposure.

The relatively high frequency of $\mathrm{HH}$ in Caucasians $(0.3 \%)^{2,23}$ highlights the possibility that patients with $\mathrm{HH}$ may coincidentally develop other neurodegenerative movement disorders such as idiopathic PD and essential tremor. ${ }^{6,7} \mathrm{Few}$ authors have reported a positive correlation between $\mathrm{HH}$ and idiopathic PD., ${ }^{9,24,25}$ However, larger studies have shown no correlation between $H F E$ mutation and the risk of idiopathic $\mathrm{PD},{ }^{26-28}$ and one group suggested the presence of the C282Y HFE mutation may be protective against the development of idiopathic $\mathrm{PD}^{26}$ The parkinsonism in patient 1 was asymmetrical and resembled idiopathic PD. However, its development in the setting of pathological brain iron deposition indicates a secondary cause related to $\mathrm{HH}$. The initial improvement of parkinsonism with levodopa can also occur in secondary parkinsonism, such as vascular parkinsonism ${ }^{29}$ and Parkinson-plus syndromes such as multiple system atrophy. ${ }^{30}$ Thus, a trial of levodopa for parkinsonism associated with $\mathrm{HH}$ is indicated. The long-term response to levodopa in this case, however, is unpredictable.

Other movement disorders have also been reported in $\mathrm{HH}$. We describe, for the first time, chorea associated with HH. Chorea was reported in one patient with $\mathrm{HH}$ who was later confirmed to have HD, however. ${ }^{7}$ The chorea in patient 2 was most likely attributed to iron deposition in the caudate nuclei. The postural and action tremor in patient 3 resembled essential tremor. However, pathological brain iron deposition in the bilateral dentate nuclei, red nuclei, and substantia nigra suggests her tremor being likely secondary to $\mathrm{HH}$.

\section{Conclusion}

We present three unique cases of $\mathrm{HH}$ associated with different movement disorders. Although two of them had evidence of iron overload in their liver, none of our patients had any major systemic manifestations. The availability of NGS helps to identify non-HFE mutations in $\mathrm{HH}$ patients, which may act as genetic modifiers of the phenotypic presentation of HFE mutations. We report the first case of chorea associated with $\mathrm{HH}$. Patient 1 developed parkinsonism as the initial presentation of $\mathrm{HH}$, which was levodopa-responsive. Patient 3 presented with head and bilateral upper extremity tremor responsive to propranolol.

The clinical-radiological correlation between the sites of brain iron deposition and neurological manifestations is demonstrated in our HH patients. The literature supports iron deposition in the basal ganglia and cerebellum on brain pathology in $\mathrm{HH}$. Finally, the stabilization or reversal of neurological features on normalization of iron stores by phlebotomy in few reported cases indicates that the neurological involvement in $\mathrm{HH}$ appears to be more than probabilistic. We propose the term "neurohemochromatosis" for HH patients presenting with predominant neurological features (movement disorders in our cases) in the absence of any major systemic manifestations of $\mathrm{HH}$. $\mathrm{HH}$ should be considered in the differential diagnoses of movement disorders with pathological iron deposition in the brain, because normalization of iron stores early in the disease process may result in complete recovery or stabilization of the neurological manifestations, including movement disorders. In addition to phlebotomy, appropriate drug treatment depending on the phenotype of movement disorders should be considered.

\section{DISCLOSURES}

NK, PR, BS, and PCA report no disclosures relevant to this manuscript. MJ receives speaker and consultant honoraria from Merz Pharmaceuticals, Allergan, AbbVie; research grants from CIHR, AMOSO, Allergan, Merz Pharmaceuticals, and Lawson Health Research Institute; is part of the AGE-WELL Network of 


\begin{tabular}{|c|c|c|c|c|c|c|c|}
\hline References & $\begin{array}{l}\text { No. of } \\
\text { cases } \\
\text { (M:F) }\end{array}$ & Onset (years) & Movement disorders & Neuroimaging (brain CT/MRI) & Systemic features & Genetic testing & Treatment \\
\hline Jones et al ${ }^{3}$ & $2(2: 0)$ & 71,52 & $\begin{array}{ll}\text { - } & \text { Ataxia } \\
\text { - } & \text { Parkinsonism } \\
\text { - } & \text { Myoclonus }\end{array}$ & $\begin{array}{l}\text { BG calcification and } \\
\text { slight sulcal } \\
\text { prominence on } \\
\text { CT brain }\end{array}$ & $\begin{array}{ll}\text { - } & \mathrm{DM}(\mathrm{n}=1) \\
\text { - } & \text { Skin pigmentation } \\
& (\mathrm{n}=1) \\
\text { - } & \text { Liver biopsy } \\
& \text { suggestive of } \mathrm{HH}\end{array}$ & - & $\begin{array}{l}\text { - No improvement with } \\
\text { phlebotomy }\end{array}$ \\
\hline $\begin{array}{l}\text { Schroder } \\
\text { et al }^{4}\end{array}$ & $1(0: 1)$ & 75 & $\begin{array}{l}\text { - Parkinsonism } \\
\text { - Tremor } \\
\text { - Gait disturbance }\end{array}$ & - $\mathrm{T} 2$ decrease in GP & $\begin{array}{ll}\text { - Skin pigmentation } \\
\text { - Cardiac } \\
\text { insufficiency }\end{array}$ & - & $\begin{array}{l}\text { - Improvement with levodopa, } \\
\text { amantadine, } \\
\text { anticholinergics, and } \\
\text { phlebotomy }\end{array}$ \\
\hline $\begin{array}{r}\text { Nielsen } \\
\text { et al }^{5}\end{array}$ & $1(1: 0)$ & 26 & $\begin{array}{l}\text { - } \text { Parkinsonism } \\
\text { - Ataxia } \\
\text { - Tremor }\end{array}$ & $\begin{array}{l}\text { T2 decrease in } \mathrm{CN} \text {, } \\
\mathrm{GP}, \mathrm{RN}, \mathrm{SN} \text {, and DN }\end{array}$ & $\begin{array}{ll}\text { - } & \text { Skin pigmentation } \\
\text { - } & \text { Liver MRI and } \\
\text { biopsy } \\
\text { suggestive of } \mathrm{HH}\end{array}$ & $\begin{array}{l}\text { HLA-A2, } \\
\text { A3, B7, B44 }\end{array}$ & $\begin{array}{l}\text { Levodopa improved } \\
\text { Parkinsonism }\end{array}$ \\
\hline $\begin{array}{c}\text { Demarquay } \\
\text { et al }^{6}\end{array}$ & $3(2: 1)$ & $56,31,70$ & $\begin{array}{l}\text { - Ataxia } \\
\text { - } \text { Parkinsonism } \\
\text { - Tremor } \\
\text { - } \text { Myoclonus } \\
\text { - } \text { Dystonia } \\
\text { - Cognitive decline }\end{array}$ & $\begin{array}{ll}\text { - } & \text { Cerebral and } \\
\text { cerebellar atrophy } \\
\text { - } \mathrm{T} 2 \text { increase in bilateral } \\
\text { striatum and WM }\end{array}$ & $\begin{array}{ll}\text { - } & \mathrm{DM}(\mathrm{n}=1) \\
\text { - } & \text { Skin pigmentation } \\
(\mathrm{n}=1) & \\
\text { - } & \text { Arthritis }(\mathrm{n}=1) \\
\text { - } & \text { Liver biopsy } \\
& \text { suggestive of } \mathrm{HH}\end{array}$ & $\begin{array}{ll}\text { - } & \mathrm{C} 282 \mathrm{Y} \\
& \text { homozygous }\end{array}$ & $\begin{array}{l}\text { - No improvement with } \\
\text { phlebotomy }\end{array}$ \\
\hline Ruso et al ${ }^{7}$ & $1(0: 1)$ & 59 & $\begin{array}{ll} & \text { Ataxia } \\
\text { - } & \text { Chorea } \\
\text { - } & \text { Dystonia } \\
\text { - } & \text { Cognitive decline }\end{array}$ & $\begin{array}{l}\text { - } \begin{array}{l}\text { Calcification of } \\
\text { choroid plexus on CT }\end{array}\end{array}$ & \begin{tabular}{ll|} 
- & Abnormal LFT \\
- Skin pigmentation \\
- Liver biopsy showed \\
iron overload
\end{tabular} & $\begin{array}{ll} & \mathrm{C} 282 \mathrm{Y} \\
& \text { homozygous } \\
\text { - } & \text { Positive HD } \\
& \text { gene testing }\end{array}$ & $\begin{array}{l}\text { - No improvement with } \\
\text { phlebotomy }\end{array}$ \\
\hline Dethy et $\mathrm{al}^{8}$ & $1(0: 1)$ & 61 & $\begin{array}{l}\text { - } \text { Parkinsonism } \\
\text { - Ataxia } \\
\text { - RLS }\end{array}$ & - Normal & $\begin{array}{l}\text { - Increased liver } \\
\text { iron on MRI }\end{array}$ & - $\mathrm{C} 282 \mathrm{Y}$ & $\begin{array}{l}\text { - Improvement with } \\
\text { phlebotomy }\end{array}$ \\
\hline $\begin{array}{l}\text { Costello } \\
\text { et al }{ }^{9}\end{array}$ & $4(3: 1)$ & $55,61,62,63$ & - Parkinsonism & $\begin{array}{l}\text { - Normal } \\
\text { - One patient had vas- } \\
\text { cular lesions on CT }\end{array}$ & $\begin{array}{ll}\text { - } & \text { DM }(\mathrm{n}=3) \\
\text { - } & \text { Skin pigmentation } \\
& (\mathrm{n}=1) \\
\text { - } & \text { Abnormal LFT } \\
& (\mathrm{n}=1) \\
\text { - } & \text { Hepatic siderosis }\end{array}$ & $\begin{array}{ll}\cdot & \text { C282Y } \\
- & \text { HLA-A2 } \\
& \text { A3 B7 B12 }\end{array}$ & $\begin{array}{l}\text { - No improvement with } \\
\text { phlebotomy } \\
\text { - Levodopa responsive }\end{array}$ \\
\hline
\end{tabular}




\begin{tabular}{|c|c|c|c|c|c|c|c|}
\hline $\begin{array}{l}\text { Rosana } \\
\text { et }^{10}{ }^{10}\end{array}$ & $1(1: 0)$ & 60 & $\begin{array}{l}\text { - } \text { Parkinsonism } \\
\text { - Tremor }\end{array}$ & $\begin{array}{l}\text { T1 increase and T2 } \\
\text { decrease in GP and P } \\
\text { bilaterally }\end{array}$ & $\begin{array}{ll}\text { - } & \text { Skin pigmentation } \\
\text { - } & \text { Arthritis on } \\
\text { radiography } \\
\text { - Liver biopsy } \\
\text { suggestive of mild } \\
\text { fibrosis }\end{array}$ & $\begin{array}{ll}- & \mathrm{C} 282 \mathrm{Y} \\
& \text { homozygous }\end{array}$ & $\begin{array}{l}\text { - No improvement with } \\
\text { phlebotomy and levodopa } \\
\text { - Improved with DBS }\end{array}$ \\
\hline $\begin{array}{l}\text { Rutgers } \\
\text { et } \mathrm{al}^{11}\end{array}$ & $1(0: 1)$ & 69 & $\begin{array}{l}\text { - Chronic } \\
\text { cerebellar ataxia }\end{array}$ & $\begin{array}{l}\text { - } \mathrm{T} 2 \text { decrease in } \\
\text { bilateral } \mathrm{P} \text { and } \mathrm{DN}\end{array}$ & $\begin{array}{l}\text { - Skin pigmentation } \\
\text { - Hepatic siderosis on } \\
\text { CT abdomen }\end{array}$ & $\begin{array}{ll}- & \mathrm{C} 282 \mathrm{Y} \\
& \text { homozygous }\end{array}$ & - Stabilized with phlebotomy \\
\hline $\begin{array}{l}\text { Di Filippo } \\
\text { et al }^{12}\end{array}$ & $1(1: 0)$ & 40 & $\begin{array}{l}\text { MSA-C (ataxia, OH, } \\
\text { abnormal bladder } \\
\text { function) }\end{array}$ & $\begin{array}{l}\text { - OPCA } \\
\text { intensity in the pons } \\
\text { ("hot cross bun" sign) }\end{array}$ & $\begin{array}{l}\text { - Hepatomegaly on } \\
\text { abdominal } \\
\text { examination } \\
\text { - Increased liver iron } \\
\text { on biopsy }\end{array}$ & $\begin{array}{ll}\text { - } & \text { H63D } \\
& \text { homozygous }\end{array}$ & - \\
\hline $\begin{array}{l}\text { Williams } \\
\text { et }^{13}{ }^{13}\end{array}$ & $1(0: 1)$ & 60 & $\begin{array}{l}\text { MSA-P } \\
\text { (parkinsonism, OH, } \\
\text { abnormal bladder } \\
\text { function) }\end{array}$ & - Normal & $\begin{array}{ll}\text { - } & \text { Mild } \\
\text { increase in ALT } \\
\text { - } & \text { Liver positive for } \\
\text { iron (postmortem) }\end{array}$ & $\begin{array}{ll}- & \mathrm{C} 282 \mathrm{Y} \\
& \text { homozygous }\end{array}$ & - Deceased \\
\hline Our study & $3(2: 1)$ & $57,61,56$ & $\begin{array}{l}\text { - Parkinsonism } \\
\text { - Chorea } \\
\text { - Tremor }\end{array}$ & $\begin{array}{l}\text { T1 increase in GP and } \\
\text { SN bilaterally } \\
\text { - Low signal on SWI in } \\
\text { CN, LN, SN, Th, and } \\
\text { DN bilaterally }\end{array}$ & $\begin{array}{ll}\text { - } & \text { Abnormal liver } \\
\text { Fibroscan* }(\mathrm{n}=1) \\
\text { - } \\
\text { Increased liver iron } \\
\text { on MRI }(\mathrm{n}=1), \text { and } \\
\text { biopsy }(\mathrm{n}=1)\end{array}$ & $\begin{array}{ll}- & \mathrm{C} 282 \mathrm{Y} \\
& \text { homozygous }\end{array}$ & $\begin{array}{l}\text { Improved with drug } \\
\text { treatment }\end{array}$ \\
\hline
\end{tabular}

$\mathrm{ALT}=$ alanine aminotransferase $; \mathrm{BG}=$ basal ganglia $; \mathrm{CN}=$ caudate nucleus; $\mathrm{DBS}=$ deep brain stimulation; $\mathrm{DM}=$ diabetes mellitus $; \mathrm{DN}=$ dentate nucleus $; \mathrm{F}=$ female $; \mathrm{GP}=$ globus pallidus $;$ $\mathrm{HH}=$ hereditary hemochromatosis; HD = Huntington disease; LFT = liver function test $\mathrm{LN}=$ lentiform nucleus; $\mathrm{M}=$ male; MSA-C = multiple system atrophy, cerebellar type; MSA-P = multiple system atrophy, parkinsonian type; OPCA = olivopontocerebellar atrophy; OH: orthostatic hypotension; P: putamen; RLS: restless legs syndrome; RN: red nucleus; SN: substantia nigra; $\mathrm{Th}=$ thalamus; $\mathrm{WM}=$ white matter.

*Liver Fibroscan $=$ transient elastography for the measurement of liver fibrosis. 
Centers of Excellence (NCE) of Canada program; and from time to time, serves on advisory boards of Allergan, Boston Scientific, AbbVie, and Merz Pharmaceuticals.

\section{STATEMENT OF AUTHORShIP}

NK undertook the conception, design, and writing the first manuscript. PR Dr. Rizek undertook the conception, review, and critique of the article. BS undertook sequencing and interpretation. PCA undertook the review and critique. MJ undertook the review and critique.

\section{REFERENCES}

1. Franchini M, Veneri D. Hereditary hemochromatosis. Hematology. 2005;10:145-9.

2. Datz C, Haas T, Rinner H, Sandhofer F, Patsch W, Paulweber B. Heterozygosity for the $\mathrm{C} 282 \mathrm{Y}$ mutation in the hemochromatosis gene is associated with increased serum iron, transferrin saturation, and hemoglobin in young women: a protective role against iron deficiency? Clin Chem. 1998;44:2429-32.

3. Jones HR, Hedley-Whyte ET. Idiopathic hemochromatosis (IHC): dementia and ataxia as presenting signs. Neurology. 1983;33:1479-83.

4. Schröder J, Haan J. [Extrapyramidal syndrome in idiopathic hemochromatosis. Significance of laboratory chemical, neurophysiologic and imaging procedures (CCT, MRT)]. Nervenarzt. 1987;58:577-8

5. Nielsen JE, Jensen LN, Krabbe K. Hereditary haemochromatosis: a case of iron accumulation in the basal ganglia associated with a parkinsonian syndrome. J Neurol Neurosurg Psychiatry. 1995;59:318-21.

6. Demarquay G, Setiey A, Morel Y, Trepo C, Chazot G, Broussolle E. Clinical report of three patients with hereditary hemochromatosis and movement disorders. Mov Disord. 2000;15:1204-9.

7. Russo N, Edwards M, Andrews T, O’Brien M, Bhatia KP. Hereditary haemochromatosis is unlikely to cause movement disorders-a critical review. J Neurol. 2004;251:849-52.

8. Dethy S, Caroyer J-M. Reversible parkinsonism associated with hemochromatosis. Mov Disord. 2004;19(Suppl 9):S327-48.

9. Costello DJ, Walsh SL, Harrington HJ, Walsh CH. Concurrent hereditary haemochromatosis and idiopathic Parkinson's disease: a case report series. J Neurol Neurosurg Psychiatry. 2004;75:631-3.

10. Rosana A, La Rosa L. A case of hereditary haemochromatosis in a patient with extrapyramidal syndrome. Blood Transfus. 2007;5:241-3.

11. Rutgers MP, Pielen A, Gille M. Chronic cerebellar ataxia and hereditary hemochromatosis: causal or coincidental association? J Neurol. 2007;254:1296-7.

12. Di Filippo M, Floridi P, Rossi V, et al. A young patient with type C multiple system atrophy and hereditary hemochromatosis. J Neurol. 2010;257:294-5.
13. Williams S, Vinjam MR, Ismail A, Hassan A. A parkinsonian movement disorder with brain iron deposition and a haemochromatosis mutation. J Neurol. 2013;260:2170-1.

14. Dusek P, Jankovic J, Le W. Iron dysregulation in movement disorders. Neurobiol Dis. 2012;46:1-18.

15. Nandar W, Connor JR. HFE gene variants affect iron in the brain. J Nutr. 2011;141:729S-39S.

16. Connor JR, Lee SY. HFE mutations and Alzheimer's disease. J Alzheimers Dis. 2006;10:267-76.

17. Scully R, Galbadini J, McNelly B. Case records of the Massachusetts General Hospital: case 17-1979. N Engl J Med. 1980;300: 969-76.

18. Aquino D, Bizzi A, Grisoli M, et al. Age-related iron deposition in the basal ganglia: quantitative analysis in healthy subjects. Radiology. 2009;252:165-72.

19. Berg D, Hoggenmüller U, Hofmann E, et al. The basal ganglia in haemochromatosis. Neuroradiology. 2000;42:9-13.

20. Beutler E, Felitti V, Gelbart T, Ho N. Genetics of iron storage and hemochromatosis. Drug Metab Dispos. 2001;29:495-9.

21. Johnstone D, Milward EA. Molecular genetic approaches to understanding the roles and regulation of iron in brain health and disease. J Neurochem. 2010;113:1387-402.

22. Merryweather-clarke AT, Cadet E, Bomford A, et al. Digenic inheritance of mutations in HAMP and HFE results in different types of haemochromatosis. Hum Mol Genet. 2003;12:2241-7.

23. Steinberg KK, Cogswell ME, Chang JC, et al. Prevalence of C282Y and H63D mutations in the hemochromatosis (HFE) gene in the United States. JAMA. 2001;285:2216-22.

24. Dekker MCJ, Giesbergen PC, Njajou OT, et al. Mutations in the hemochromatosis gene (HFE), Parkinson's disease and parkinsonism. Neurosci Lett. 2003;348:117-9.

25. Guerreiro RJ, Bras JM, Santana I, et al. Association of HFE common mutations with Parkinson's disease, Alzheimer's disease and mild cognitive impairment in a Portuguese cohort. BMC Neurol. 2006;6:24.

26. Buchanan DD, Silburn PA, Chalk JB, Le Couteur DG, Mellick GD. The Cys282Tyr polymorphism in the HFE gene in Australian Parkinson's disease patients. Neurosci Lett. 2002;327:91-4.

27. Borie C, Gasparini F, Verpillat P, et al. Association study between iron-related genes polymorphisms and Parkinson's disease. J Neurol. 2002;249:801-4.

28. Biasiotto G, Goldwurm S, Finazzi D, et al. HFE gene mutations in a population of Italian Parkinson's disease patients. Parkinsonism Relat Disord. 2008;14:426-30.

29. Demirkiran M, Bozdemir H, Sarica Y. Vascular parkinsonism: a distinct, heterogeneous clinical entity. Acta Neurol Scand. 2001;104:63-7.

30. Jankovic J. Parkinson's disease: clinical features and diagnosis. J Neurol Neurosurg Psychiatry. 2008;79:368-76. 